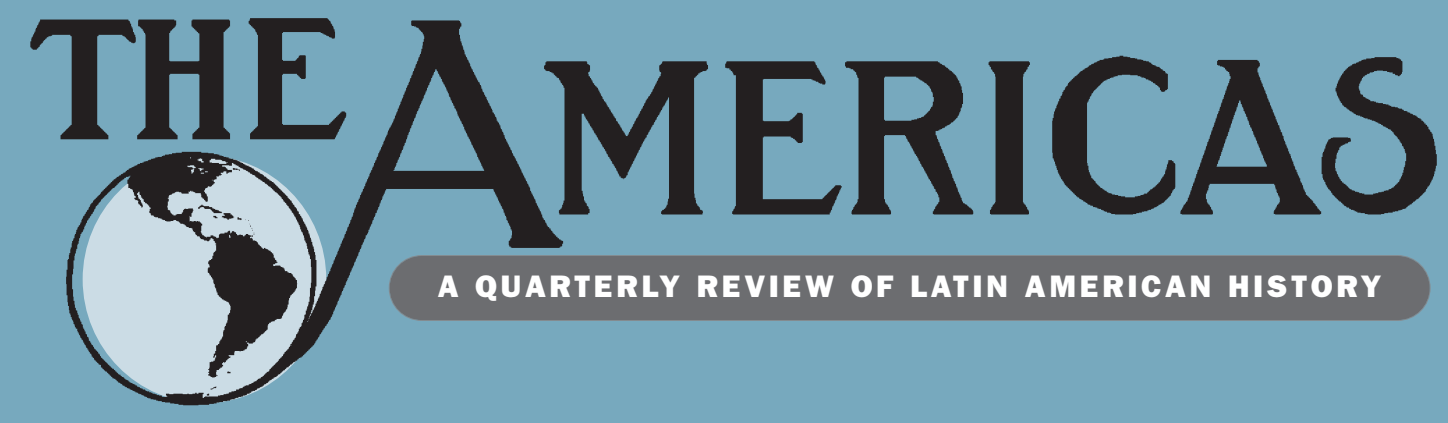

V०L u $\mathrm{m} \odot \quad 73$ A p I I 2016 $\mathbb{N}$ u m b $\odot$ [ 2
NOR A H A D RE W S

CALIDAD, GENEALOGY, AND DISPUTED FREE-COLORED TRIBUTARY STATUS IN NEW SPAIN

S TAFFOR D POOLE

'E L Y D IO MAS VENTUROSO':

A Spanish Guadalupan Drama of the Early Nineteenth Century

ROBERT WEIS

P I O U D E L I N Q E N T :

Anticlericalism and Crime in Postrevolutionary Mexico

F A B R Í C IO PRA D O

TRANS-IMPERIAL NETWORKS IN THE

C RISIS OF THE S PANISH MONARCH :

The Rio de Janeiro-Montevideo Connection, 1778-1805

BOOKS IN BRIEF

REVIEWS

Published by

Academy of American

Franciscan History

CAMBRIDGE

UNIVERSITY PRESS 


\section{BOARD OF EDITORS}

JEFFREY M. BURNS, Director

Academy of American Franciscan History, USA

\section{Liason to the Academy of American Franciscan History}

JOHN F. SCHWALLER

University at Albany, USA

Editor

BEN VINSON III

George Washington University, USA

GEORGETTE MAGASSY DORN

Library of Congress, USA

BARBARA A. SOMMER

Gettysburg College, USA

ERIC ZOLOV

Stony Brook University, USA
Associate Editor

JAMES M. KRIPPNER

Haverford College, USA

Assistant Editors

LEO GAROFALO

Connecticut College, USA

Barbara A. Tenenbaum

Library of Congress, USA

ANN ZULAWSKI

Smith College, USA

Editorial Assistant

J.M.H. CLARK

Johns Hopkins University, USA
Managing Editor DONALD F. STEVENS

Drexel University, USA

MARY KARASCH

Oakland University, USA (Emeritus)

RICHARD WARREN

St. Joseph's University, USA

\section{AREA EDITORS}

KATHERINE BLISS (2019)

Southern Methodist University, USA

MATT CHILDS (2016)

University of South Carolina, USA

ERIK CHING (2018)

Furman University, USA

DEBORAH COHEN (2018)

University of Missouri, St. Louis, USA

LAUREN DERBY (2018)

University of California, Los Angeles, USA

REBECCA EARLE (2020)

University of Warwick, Great Britain
BARBARA GANSON (2017)

Florida Atlantic University, USA

CHRISTINE HunEFELT (2016)

University of California, San Diego, USA

THOMAS KLUBOCK (2018)

University of Virginia, USA

BRYAN MCCANN (2017)

Georgetown University, USA

JAMES SWEET (2018)

University of Wisconsin, Madison, USA

\section{SENIOR EDITORS}

GEORGE REID ANDREWS (2019)

University of Pittsburgh, USA DIEGo ARMUS (2020)

Swarthmore College, USA

WiLLIAM H. BEEZLEY (2018)

University of Arizona, USA

AMY Turner Bushnell (2018)

Brown University, USA

BARRY CARR (2020)

Latrobe University, Australia

JEFFREY GOULD (2018)

Indiana University, USA

LOWELL GUDMUNDSON (2015)

Mount Holyoke College, USA

HENDRIK KRAAY (2020)

University of Alberta, Canada

ERICK LANGER (2017)

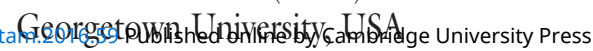

Luis Carlos ManTilla, O.F.M. (2018)

Universidad de San Buenaventura, Colombia

CHERYL MARTIN (2015)

University of Texas, El Paso, USA

AlidA C. METCALF (2015)

Rice University, USA

Francisco Morales, O.F.M. (2019)

Mexico City, Mexico

LOUIS A. PÉrEZ JR. (2017)

University of North Carolina, Chapel Hill, USA

JOANNE RAPPAPORT (2016)

Georgetown University, USA

JOÃO JOSÉ REIS (2020)

Universidade Federal da Bahia, Brazil

MATTHEW RESTALL (2016)

Pennsylvania State University, USA 


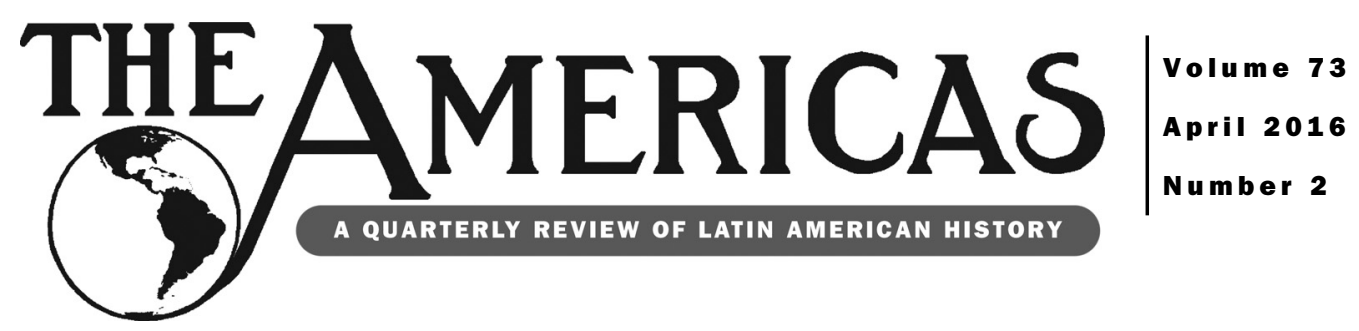

ARTICLES

139 Calidad, Genealogy, and Disputed Free-colored Tributary Status in New Spain

NORAH ANDREWS

171 'EL YNDio Mas VentURoso':

A Spanish Guadalupan Drama of the Early Nineteenth

Century

StafFord Poole

185 Pious Delinguents:

Anticlericalism and Crime in Postrevolutionary Mexico

ROBERT WEIS

211 Trans-Imperial Networks in the Crisis of the

SPANISH MONARCHY:

The Rio de Janeiro-Montevideo Connection, 1778-1805

Fabrício Prado

\section{REVIEWS \\ BOOKS IN BRIEF}

237 The Maya. 9th ed. Edited by Michael D. Coe and Stephen Houston.

239 Women and Gender in Modern Latin America: Historical Sources and Interpretations. By Pamela S. Murray.

240 The Women of Colonial Latin America. 2nd ed. By Susan Migden Socolow.

240 The Dominican Republic Reader: History, Culture, Politics. Edited by Eric Paul Roorda, Lauren H. Derby, and Raymundo Gonzalez.

249 Keen's Latin American Civilization Volume One: The Colonial Era. 10th ed. Edited by Robert M. Buffington and Lila Caimari.

252 Keen's Latin American Civilization Volume Two: The Modern Era. 10th Ed. Edited by Robert M. Buffington and Lila Caimari. 


\section{BOOK NOTE}

255 Lexikon of the Hispanic Baroque: Transatlantic Exchange and Transformation. Edited by Evonne Levy and Kenneth Mills James Krippner

\section{REVIEWS}

257 Revolution in the Andes: The Age of Túpac Amaru. By Sergio Serulnikov.

The Tupac Amaru Rebellion. By Charles F. Walker.

\section{Marcela Echeverri}

AFRICANA, SLAVERY, AND DIASPORA STUDIES

260 Biography and the Black Atlantic. Edited by Lisa A. Lindsay and John Wood Sweet.

\section{Elizabeth J. West}

262 Divining Slavery and Freedom: The Story of Domingos Sodré, an African Priest in Nineteenth-Century Brazil. By João José Reis Zephyr Frank

264 Slave Families and the Hato Economy in Puerto Rico. By David M. Stark.

\section{Jorge L. Chinea}

\section{CULTURAL/LITERARY STUDIES}

266 Making Samba: A New History of Race and Music in Brazil. By Marc Hertzman.

\section{Paulina L. Alberto}

268 Salsa World: A Global Dance in Local Contexts. By Sydney Hutchinson.

\section{Deborah Pacini Hernandez}

270 Language and Ethnicity among the K'ichee' Maya. By Sergio Romero.

\section{Mary Jill Brody}

272 The Untranslatable Image: A Mestizo History of the Arts in New Spain, 1500-1600. By Alessandra Russo.

\section{Barbara E. Mundy}




\section{ENVIRONMENTAL HISTORY}

274 Sea of Storms: A History of Hurricanes in the Greater Caribbean from Columbus to Katrina. By Stuart B. Schwartz.

\section{Ann Zulawski}

\section{GLOBAL AND TRANSNATIONAL HISTORY}

276 Cubans in Angola: South-South Cooperation and Transfer of Knowledge, 1976-1991. By Christine Hatzky.

\section{Horace G. Campbell}

277 Imperialism and the Origins of Mexican Culture. By Colin MacLachlan.

\section{Susan Kellogg}

279 We Are Left without a Father Here: Masculinity, Domesticity, and Migration in Postwar Puerto Rico. By Eileen J. Suárez Findlay.

\section{Solsiree del Moral}

\section{POLITICS/GOVERNANCE}

282 The Work of Recognition: Caribbean Colombia and the Postemancipation Struggle for Citizenship. By Jason McGraw.

Jaime Arocha

284 Rethinking Community from Peru: The Political Philosophy of José Maria Arguedas. By Irina Alexandra Feldman.

Jon Beasley-Murray

\section{RELGION/RELIGIOUS PRACTICES}

286 Tezcatlipoca: Trickster and Supreme Deity. Edited by Elizabeth Baquedano.

John F. Schwaller 


\section{CONTRibutors}

Norah Andrews is Visiting Assistant Professor in Latin American History at Northern Arizona University. She is a historian of colonial Afromexico currently working on a book manuscript titled "Taxing Blackness: Free-Colored Tribute in Colonial Mexico." In 2010-11, she conducted archival research with the support of a Mellon Dissertation Fellowship in the Humanities in Original Sources from the Council on Library and Information Resources.

Stafford Poole is a Catholic priest in the Congregation of the Mission (Vincentian Community). His primary interest is in colonial Mexico, especially the Mexican church councils and the devotion to Our Lady of Guadalupe. His latest work (2015) is a translation and commentary on Lorenzo Boturini Benaduci's Idea de una nueva historia general de la America Septentrional. He is retired and lives in Los Angeles.

Fabrício Prado is Assistant Professor of History at the College of William and Mary in Williamsburg, Virginia, where he teaches classes on Latin America and the Atlantic World. Prado is the author of Colonia do Sacramento: o extremo sul da América portuguesa (2002) and Edge of Empire: Atlantic Networks and Revolution in Bourbon Rio de la Plata (2015).

Robert Weis is Associate Professor of History at the University of Northern Colorado. He is the author of Bakers and Basques: A Social History of Bread in Mexico (2012) and is currently working on a collective biography of young Catholic activists in Mexico City during the 1920s. 